\title{
Sexual Dimorphism of Femur and its Clinical Significance
}

\author{
Ranzeetha. D. K. V. Pavana Kumari ${ }^{1}$ \\ ${ }^{1}$ Assistant Professors of Anatomy, Guntur Medical College, Guntur, Andhra Pradesh, India.
}

\section{Abstract}

Introduction: Assessment of human sex from skeletal remains plays a key role in anthropological and medico legal studies. Hence this study was taken to assess the sex form an isolated bone i.e. femur, with as far as possible minimal parameters to ascertain the sex. Subjects and Methods: A study was conducted with 100 non pathological femora. (50male, 50 females ) in different age groups of known sex. The present study was to determine the sex by using 5 parameters i.e Maximum length, Head vertical diameter, Transverse head diameter, Proximal breadth, Distal breadth of the femur has been taken because it gives some useful data in medico legal cases, When only the remains of femur bone were left in deceased individuals. The measurements of femur bone were taken with the help of osteometric board and Vernier calliper. Results: The readings were noticed. The readings were tabulated and subjected to statistical analysis. It was noticed that all the studied parameters were greater in males than in females. Conclusion: The present study on the determination of sex of femora will be more reliable basis for the sex determination because it shows the values in this geographical region. This is believed to be more useful in the investigative procedures in the Forensic Medicine and also in the field of orthopaedics.

Keywords: Femur, sexual dimorphism, Maximum length, Head vertical diameter, Transverse head diameter, Proximal breadth, Distal breadth.

Corresponding Author: Dr. K.V. Pavana Kumari, Assistant Professor, Department of Anatomy, Guntur Medical College, Guntur, Andra Pradesh, India.

Received: June 2019

Accepted: June 2019

\section{Introduction}

Determination of Sex is relatively easy if the entire skeleton is available for examination. Skull and pelvis are the most reliable bones for sex determinatination. ${ }^{[1]}$ However in medico legal cases, one does not always have a complete pelvis or skull. Therefore it is important to be able to assess sex from the other parts of the skeleton also. Femur is the most useful of the long bone. Its length and massiveness themselves being significant in suggesting sex (Krishan Vij, MD, LLB Forensic Medicine and Toxicology 5th edition 2011). ${ }^{[32]}$ On the whole, the bones of a male skeleton are heavier and larger, and markings for the muscular attachments are more pronounced than in the female. This helps in determining the sex of the deceased individual from examination of bones procured from the site.

Femur is widely studied to determine the stature and locomotion patterns, for sex identification in skeletal remains as it shows significant variation between individuals. $^{[4-8]}$

To find out the actual measurements of the femur basing on different variable factors in this geographical region and to obtain the results to the highest possible accuracy.

The results of this study will certainly be useful in various ways such as

1. In Medico Legal cases - a) In forensic medicine, in determining the sex of the individual especially in case of fragmentation of the bone. The current practice whereby criminals dismember the remains of their victims in an attempt to make their identification difficult requires that simple methods of sex determination from fragmented skeletal remains are available to forensic anthropologists and skeletal biologists. The head of the femur is an example of such bone fragments. Identification and demarking points have been derived from the diameters of the head of the femur and used o determine the sex of individuals. ${ }^{[23]}$

b) The distal end of the femur is the only epiphysis in which ossification consistently starts just before birth: the phenomenon therefore serves as a reliable indicator of the gestational maturity of the still born baby (Susan standring et al - text of Gray's Anatomy-40th edition-2008). ${ }^{[31]}$

2. In understanding the biomechanics wherever the femur is involved, and also

3. In the Orthopaedic practice of bone reconstructive or replacement procedures.

\section{Aim:}

The aim of the study was taken to assess the sex from an isolated bone that is femur, with various parameters to ascertain the sex.

\section{Subjects and Methods}


The present study was conducted in the department of anatomy in Guntur medical college, Guntur and katuri medical college, chinakondrupadu on 100 non pathological dried adult femora (50males \& 50 females) of known sex were used for the present study. All the bones had completed femoral growth as evidenced by the complete fusion of the proximal \& distal femoral epiphysis. They were cleaned well without soft tissue or cartilage and were thoroughly dried. Some Of the Femora which were grossly deformed and Fragmented were excluded.

Maximum length, Head vertical diameter, Transverse head diameter, proximal breadth, distal breadth of the femur were measured as mentioned below.

Maximum length (ML)- of femur was measured on osteometric board in such a manner that medial condyle touches the shot vertical wall, The moveable cross piece should touch the highest point of the head.

Transverse diameter of head (TDH)- Straight distance between the most laterally projected points perpendicular to the vertical diameter of head.

Vertical diameter of head (VDH)- The work piece of vernier calliper was placed as close to the surface of the head as possible ensuring perfect contact of the measuring surface with work piece, and the straight distance between the highest and lowest point of the head.

Proximal breadth (PB)- The distance from most medially placed point on the head to the most laterally placed point on greater trochanter was measured by using a vernier caliper.

Distal breadth(DB) or Bicondylar breadth width(BB)Maximum distance between medial and lateral epicondyles in coronal plane at right angle to the long axis of femur was measured in millimetre with the help of vernier calliper.

Photographs of femora showing the method of taking the above 5 parameters are displayed [Figure 1-5]

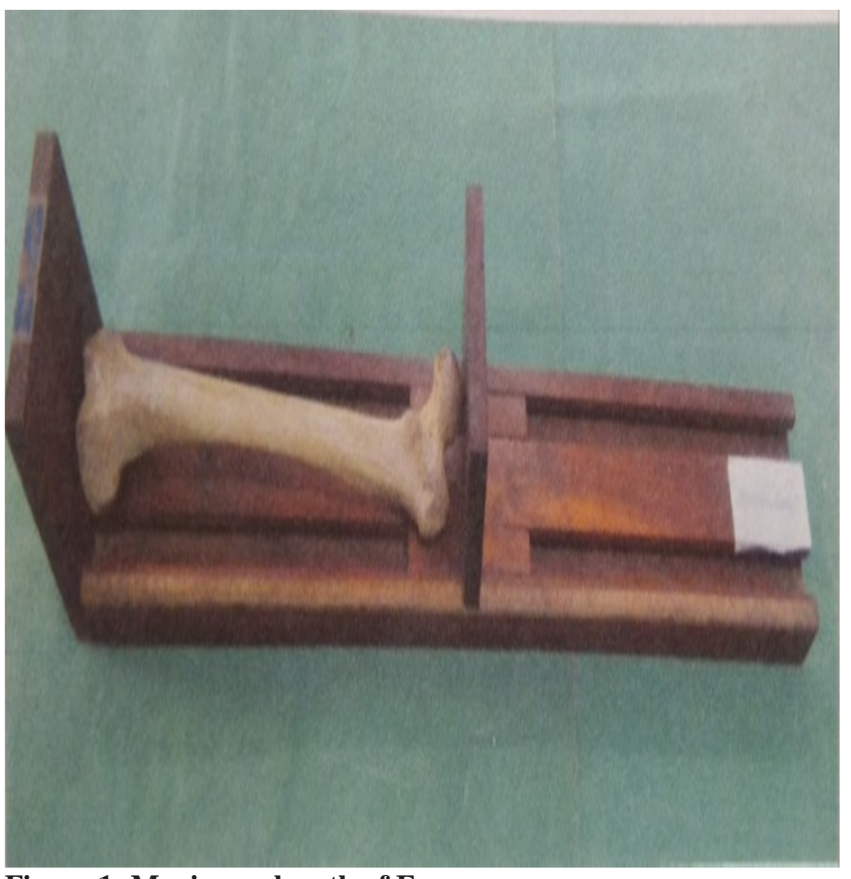

Figure 1: Maximum length of Femur

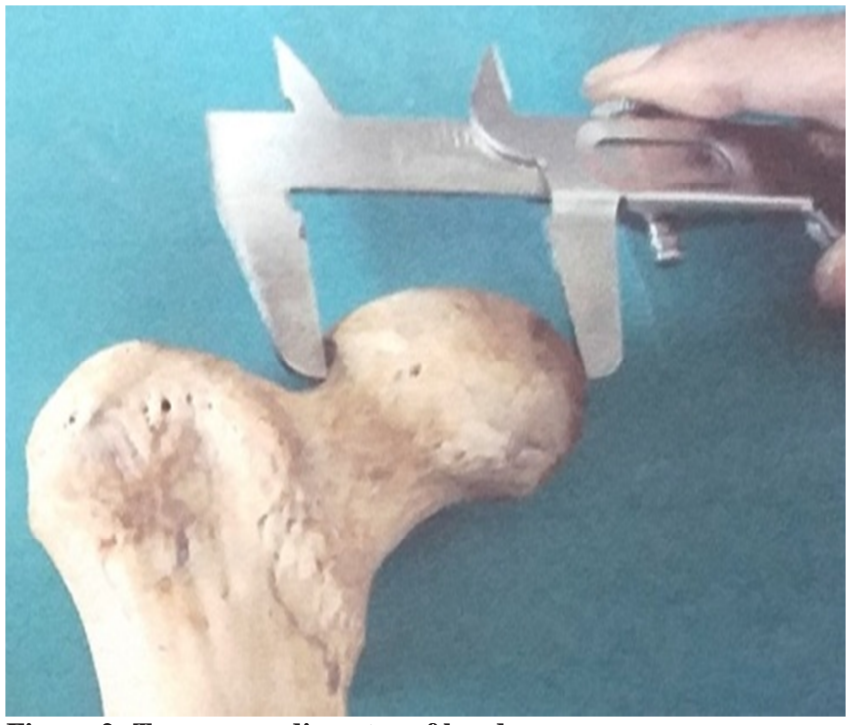

Figure 2: Transverse diameter of head

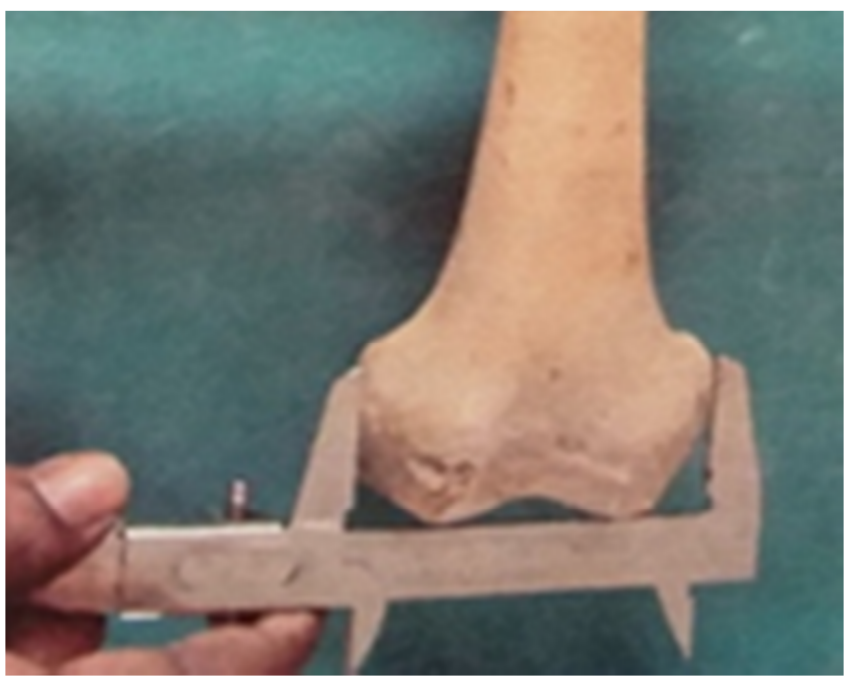

Figure 3: Distal breadth

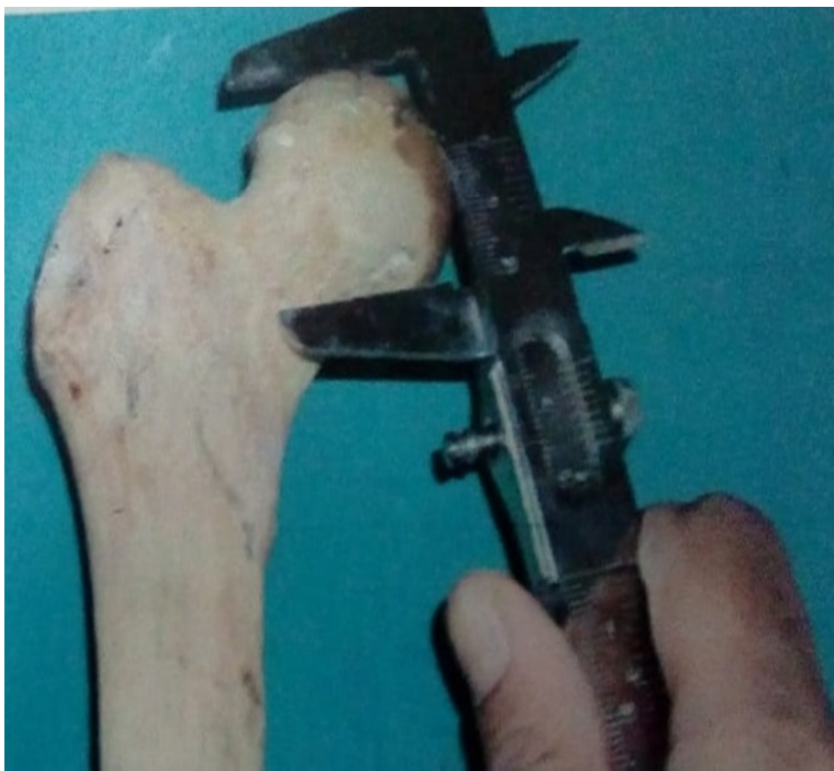

Figure 4: Head vertical diameter 


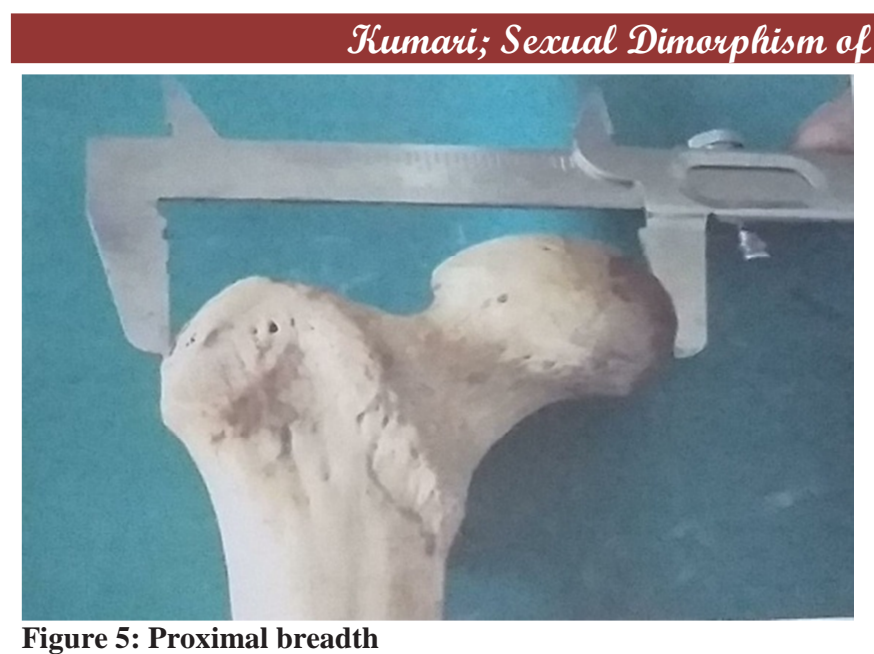

\section{Results}

By analyzing the present study the following parameters of femur in male -maximum length, head vertical diameter, transverse diameter of head, proximal breadth, distal breadth where more than female which are statistically significant ( $p$ value $<0.001$ )

Five parameters were taken into consideration while undertaking the antropometric study. These factors are of academic interest as they are very variable. This fact of variability is mentioned by almost all authors. As such these factors are mentioned in this study also as "variable factors".

The minimum value and maximum value mean, standard deviation and level of significance of all the five parameters of adult male and female femora were calculated using the standard statistical methods and the readings were tabulated as shown in the [Table $1 \& 2$ ]

Table 1: Minimum and Maximum values, Statistical analysis of all Five parameters of adult male femora

\begin{tabular}{|l|l|l|l|l|l|}
\hline Parameters & $\begin{array}{l}\text { Minimum } \\
(\mathbf{m m})\end{array}$ & $\begin{array}{l}\text { Maximum } \\
(\mathbf{m m})\end{array}$ & $\begin{array}{l}\text { Mean } \\
(\mathbf{m m})\end{array}$ & S.D. & $\begin{array}{l}\text { P } \\
\text { value }\end{array}$ \\
\hline $\begin{array}{l}\text { Maximum } \\
\text { length }\end{array}$ & 403 & 482 & 444.7 & 19.45 & $<0.001$ \\
\hline $\begin{array}{l}\text { Head vertical } \\
\text { diameter }\end{array}$ & 38.1 & 45.3 & 42.08 & 1.93 & $<0.001$ \\
\hline $\begin{array}{l}\text { Transverse } \\
\text { diameter of } \\
\text { head }\end{array}$ & 39.2 & 46.2 & 42.93 & 1.82 & $<0.001$ \\
\hline $\begin{array}{l}\text { Proximal } \\
\text { breadth }\end{array}$ & 76.5 & 85.2 & 82.13 & 2.05 & $<0.001$ \\
\hline Distal breadth & 69.2 & 82.5 & 74.79 & 2.97 & $<0.001$ \\
\hline
\end{tabular}

Table 2: Minimum and maximum values, Statistical analysis of all five parameters of adult female femora

\begin{tabular}{|l|l|l|l|l|c|}
\hline Parameters & $\begin{array}{l}\text { Minimum } \\
(\mathbf{m m})\end{array}$ & $\begin{array}{l}\text { Maximum } \\
(\mathbf{m m})\end{array}$ & $\begin{array}{l}\text { Mean } \\
(\mathbf{m m})\end{array}$ & S.D. & $\begin{array}{c}\text { P } \\
\text { value }\end{array}$ \\
\hline $\begin{array}{l}\text { Maximum } \\
\text { length }\end{array}$ & 332 & 455 & 402.9 & 31.13 & $<0.001$ \\
\hline $\begin{array}{l}\text { Head vertical } \\
\text { diameter }\end{array}$ & 32.5 & 41.6 & 37.22 & 2.02 & $<0.001$ \\
\hline $\begin{array}{l}\text { Transverse } \\
\text { diameter of } \\
\text { head }\end{array}$ & 32.5 & 42.5 & 37.66 & 2.10 & $<0.001$ \\
\hline $\begin{array}{l}\text { Proximal } \\
\text { breadth }\end{array}$ & 71.5 & 76.5 & 74.27 & 1.81 & $<0.001$ \\
\hline Distal breadth & 65.2 & 72.5 & 69.38 & 1.63 & $<0.001$ \\
\hline
\end{tabular}

\section{Discussion}

Sex determination from long bones or their fragments is often required to establish a possible identify. It is a common experience for the forensic expert to be confronted with poorly preserved or fragmentary bones. Due to the tubular structure of long bones they are often better preserved than other shorter bones. thus data for long bone measurement will be more useful.

The values found in this study are in various manners when compared with the values found by the other authors. Therefore, the values are considered as per the following guidelines:

Values with variation of upto 5 percent-"almost similar to" Values with variation of more than 5 and upto 10 percent"slightly lower / higher than"

Values with variation of more than 10 percent-"different from"

According to singh and shamer singh, ${ }^{[9,10]}$ For determining the sex of adult femora, its length is the best guide; provided it has crossed a demarcating point, -the right femora measuring $445 \mathrm{~mm}$ and above can be classified as in males and females $377 \mathrm{~mm}$. similarly left femora measuring $442 \mathrm{~mm}$ and above can be classified as male and those below $372.5 \mathrm{~mm}$ as females.

Enock prabhakar, ${ }^{[11]}$ stated $430 \mathrm{~mm}$ in males and $410 \mathrm{~mm}$ in females in north Indian population. There is no marked difference between the south Indian and North Indian populations.

According to the study of Parsons, F.G.(1914), ${ }^{[16]}$ Maximum Length was shown as more than $450 \mathrm{~mm}$ in male and lesser than $400 \mathrm{~mm}$ in female Americans. According to the study of king C.A;Iscan et.al;(1998), ${ }^{[19]}$ Maximum Length was shown as $429.4 \mathrm{~mm}$ in male and $397 \mathrm{~mm}$ in female Thais. Purkait R.and Chandra H;(2002), ${ }^{[14]}$ reported Maximum Length was shown as $451.47 \mathrm{~mm}$ in male and $403.2 \mathrm{~mm}$ in female Indians. According to the study of Rashmi Srivastava, ph.D.et.al(2011) ${ }^{[2]}$ Maximum Length was shown as $435.5 \mathrm{~mm}$ in males and $404.1 \mathrm{~mm}$ in females. This study showed the maximum length as $444.7 \mathrm{~mm}$ in males and $402.9 \mathrm{~mm}$ in females. The values found by this study are almost similar to the values of the above author's in spite of the racial difference.

Mall G, Gehring KD et.al(2000), ${ }^{[21]}$ stated that the maximum Length was shown as $464 \mathrm{~mm}$ in males and $434 \mathrm{~mm}$ in females. The present study values of the males are almost similar to that of the author's study and females are slightly lower than that of the author.

Umapathy Sembian et.al(2012), ${ }^{[12]}$ reported maximum length on the right side in the males was $406 \mathrm{~mm}$ and $388 \mathrm{~mm}$ in females, on the left side in males was $40 \mathrm{~mm}$ and in females it was found to be $388 \mathrm{~mm}$. The present study values of the males are slightly higher than that of the author. The values of females are almost similar to the values of that of author's study.

\section{Head vertical diameter-}

According to the study of Purkait R.and Chandra $\mathrm{H}$;(2002), ${ }^{[14]}$ Head vertical diameter was shown as $44.28 \mathrm{~mm}$ in male and $38.39 \mathrm{~mm}$ in female Indians. This study showed the same factor as $42.08 \mathrm{~mm}$ in males and $37.22 \mathrm{~mm}$ in 
females. The values found by this study are almost similar to that of the values of that of author's study. Parson,F.G.(1914), ${ }^{[16]}$ reported Head vertical diameter was shown as more than $48 \mathrm{~mm}$ in male and lesser than $44 \mathrm{~mm}$ in female Americans. The values found by this study are different from the values of that of author's study.

Pearson K,Bell.(1917), ${ }^{[2]}$ stated that the Head vertical diameter was shown more than $45.5 \mathrm{~mm}$ in male and lesser than $41.5 \mathrm{~mm}$ in female Americans. The values of this study showed the males are slightly lower than that of author. The values of females are different from the values of that of author's study.

\section{Transverse head diameter-}

Rashmi Srivastava, ph.D.et.al $(2011),{ }^{[2]}$ reported Transverse head diameter in males was shown as $43.86 \mathrm{~mm}$ and in females was $39.52 \mathrm{~mm}$. This study showed the same factor as $42.93 \mathrm{~mm}$ in males and $37.66 \mathrm{~mm}$ in females. The values found by this study are almost similar to the values of that of author's study.

According to thes study of Mall G, Gehring KD et.al(2000), ${ }^{[21]}$ Transverse head diameter in males was shown as $49 \mathrm{~mm}$ and in females was $43 \mathrm{~mm}$. The values of the present study are different from that of the values of that of author's study.

\section{Proximal breadth-}

According to the study of Rashmi Srivastava, ph.D.et.al(2011) ${ }^{[2]}$ Proximal breadth was shown as $85.72 \mathrm{~mm}$ in males and $75.29 \mathrm{~mm}$ in females. This study showed the same factor as $82.13 \mathrm{~mm}$ in males and $74.27 \mathrm{~mm}$ in females. The values found by this study are almost similar to that of the values of that of author's study.

\section{Distal breadth-}

According to the study of Parson,F.G.(1914), ${ }^{[16]}$ Distal breadth was shown as more than $75 \mathrm{~mm}$ in male and lesser than $70 \mathrm{~mm}$ in female Americans. Rashmi Srivastava,ph.D.et.al(2011)2- reported distal breadth was shown as $76.83 \mathrm{~mm}$ in males and $68.28 \mathrm{~mm}$ in females. This study showed the same factor as $74.79 \mathrm{~mm}$ in males and $69.38 \mathrm{~mm}$ in females. The values found by this study are almost similar to the values of that of author's study.

According to the study of king C.A;Iscan et.al;(1998), ${ }^{[19]}$ Distal breadth was shown as $79.7 \mathrm{~mm}$ in males and $70 \mathrm{~mm}$ in females. The values of the present study males are slightly lower than that of the author. The values of females are almost similar to that of author's study.

Mall G, Gehring KD et.al(2000), ${ }^{[21]}$ reported distal breadth was shown as $84 \mathrm{~mm}$ in males and $77 \mathrm{~mm}$ in females. The values found by this study are different from that of the values of that of author's study.

According to the study of Purkait R.and Chandra $\mathrm{H} ;(2002),{ }^{[14]}$ Distal breadth was shown as $78.04 \mathrm{~mm}$ in males and $67.13 \mathrm{~mm}$ in females. The values of the males are slightly lower than that of the author and females are almost similar to that of author's study

\section{Comparison of present findings with previous Authors} Maximum length

\begin{tabular}{|l|l|l|}
\hline \multirow{2}{*}{ Authors } & Maximum length \\
\cline { 2 - 3 } & Male & Female \\
\hline Parson $^{16}, 1914$ & More than & $\begin{array}{l}\text { Lesser than } \\
450 \mathrm{~mm}\end{array}$ \\
\hline King C.A,iscan M.Y and Loth & $429.4 \mathrm{~mm}$ & $397 \mathrm{~mm}$ \\
\hline
\end{tabular}

\begin{tabular}{|c|c|c|}
\hline S.R ${ }^{19}, 1998$ & & \\
\hline Mall G.Graw M,et.al $^{21}, 2000$ & $464.0 \mathrm{~mm}$ & $434.0 \mathrm{~mm}$ \\
\hline $\begin{array}{l}\text { Purkait R. and Chandra } \mathrm{H}^{14} \text {, } \\
2002\end{array}$ & $451.47 \mathrm{~mm}$ & $403.2 \mathrm{~mm}$ \\
\hline 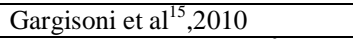 & $439.57 \mathrm{~mm}$ & $410.60 \mathrm{~mm}$ \\
\hline Rashmi Srivastava et.al $^{2} 2011$ & $435.5 \mathrm{~mm}$ & $404.1 \mathrm{~mm}$ \\
\hline $\begin{array}{l}\text { Pandya AM,Singel TC etal } \\
2011\end{array}$ & $\begin{array}{l}\text { Rt side } 451.81 \\
\text { Lt side } 453.35\end{array}$ & $\begin{array}{l}\text { Rt side } 417.48 \\
\text { Lt side } 420.44\end{array}$ \\
\hline Umapathy sembain et.al $^{12} 2012$ & $\begin{array}{l}\text { Rt. Side } 406 \mathrm{~mm} \\
\text { Lt. Side } 40 \mathrm{~mm}\end{array}$ & $\begin{array}{l}\text { Rt.side } 388 \mathrm{~mm} \\
\text { Lt.side } 388 \mathrm{~mm}\end{array}$ \\
\hline Hema Nidugala et.al ${ }^{28} 2013$ & $421.11 \mathrm{~mm}$ & $431.90 \mathrm{~mm}$ \\
\hline Rajeswari.S. et.al $^{29} 2013$ & $\begin{array}{l}\text { Rt } 406 \mathrm{~mm} \\
\text { Lt } 40 \mathrm{~mm}\end{array}$ & $\begin{array}{l}\text { Rt } 388 \mathrm{~mm} \\
\text { Lt } 388 \mathrm{~mm}\end{array}$ \\
\hline Kalpana .R. et.al ${ }^{20} 2014$ & $441.36 \mathrm{~mm}$ & $394.60 \mathrm{~mm}$ \\
\hline Pavel Timonov et.al $^{18}$ & $461.77 \mathrm{~mm}$ & $411.74 \mathrm{~mm}$ \\
\hline Rajeev vijay joshi et.al ${ }^{17} 2017$ & $436 \mathrm{~mm}$ & $421 \mathrm{~mm}$ \\
\hline Prsent study & $444.7 \mathrm{~mm}$ & $402.9 \mathrm{~mm}$ \\
\hline
\end{tabular}

Head vertical diameter

\begin{tabular}{|c|c|c|}
\hline \multirow[t]{2}{*}{ Authors } & \multicolumn{2}{|c|}{ Head vertical diameter } \\
\hline & Male & Female \\
\hline Dwight $^{26}, 1905$ & $49.68 \mathrm{~mm}$ & $43.84 \mathrm{~mm}$ \\
\hline Parson $^{16}, 1914$ & More than $48 \mathrm{~mm}$ & Lesser than $44 \mathrm{~mm}$ \\
\hline $\begin{array}{l}\text { Pearson k,Bell J. }{ }^{22} \text {, } \\
1917\end{array}$ & More than $45.5 \mathrm{~mm}$ & Lesser than $41.5 \mathrm{~mm}$ \\
\hline Stewart. TD ${ }^{27}, 1979$ & More than $47.5 \mathrm{~mm}$ & Lesser than $42.5 \mathrm{~m}$ \\
\hline $\begin{array}{l}\text { King C.A,iscan M.Y } \\
\text { and Loth S.R }{ }^{19}, 1998\end{array}$ & $45.1 \mathrm{~mm}$ & $39.3 \mathrm{~mm}$ \\
\hline $\begin{array}{l}\text { Mall G.Graw } \\
\text { M,et.al }{ }^{21}, 2000\end{array}$ & $49 \mathrm{~mm}$ & $44 \mathrm{~mm}$ \\
\hline $\begin{array}{l}\text { Purkait R. and } \\
\text { Chandra } \mathrm{H}^{14}, 2002\end{array}$ & $44.28 \mathrm{~mm}$ & $38.39 \mathrm{~mm}$ \\
\hline $\begin{array}{l}\text { K.S. Narayana } \\
\text { Reedy }^{24}, 2008 \\
\end{array}$ & More than $47 \mathrm{~mm}$ & Lesser than $45 \mathrm{~mm}$ \\
\hline Apurba nandy ${ }^{25}, 2010$ & $45 \mathrm{~mm}$ & $41.5 \mathrm{~mm}$ \\
\hline Gargisoni et.al $^{15}, 2010$ & $44.45 \mathrm{~mm}$ & $39.89 \mathrm{~mm}$ \\
\hline $\begin{array}{l}\text { Rashmi Srivastava } \\
\text { e.tal }^{2}, 2011\end{array}$ & $43.77 \mathrm{~mm}$ & $39.40 \mathrm{~mm}$ \\
\hline $\begin{array}{l}\text { Hema Nidugala et.al }{ }^{28} \\
2013\end{array}$ & $39.85 \mathrm{~mm}$ & $41.75 \mathrm{~mm}$ \\
\hline $\begin{array}{l}\text { Mohammed Laeeque } \\
\text { et.al }{ }^{30} 2014\end{array}$ & $43 \mathrm{~mm}$ & $37 \mathrm{~mm}$ \\
\hline $\begin{array}{l}\text { Rajeev vijay joshi } \\
\text { et.al }^{17} 2017\end{array}$ & $42.0 \mathrm{~mm}$ & $41.7 \mathrm{~mm}$ \\
\hline Present study & $42.08 \mathrm{~mm}$ & $37.22 \mathrm{~mm}$ \\
\hline
\end{tabular}

Transverse head diameter

\begin{tabular}{|l|l|l|}
\hline \multirow{2}{*}{ Authors } & \multicolumn{2}{|l|}{ Transverse diameter of head } \\
\cline { 2 - 3 } & Male & Female \\
\hline Mall G.Graw M, et.al ${ }^{21}, 2000$ & $49 \mathrm{~mm}$ & $43 \mathrm{~mm}$ \\
\hline Rashmi Srivastava et.al ${ }^{2}, 2011$ & $43.86 \mathrm{~mm}$ & $39.52 \mathrm{~mm}$ \\
\hline Hema Nidugala et.al $^{28} 2013$ & $35.31 \mathrm{~mm}$ & $36.81 \mathrm{~mm}$ \\
\hline Mohammed Laeeque et.al ${ }^{30} 2014$ & $43 \mathrm{~mm}$ & $37 \mathrm{~mm}$ \\
\hline Rajeev vijay joshi et.al ${ }^{17} 2017$ & $42.0 \mathrm{~mm}$ & $41.7 \mathrm{~mm}$ \\
\hline Present Study & $42.93 \mathrm{~mm}$ & $37.66 \mathrm{~mm}$ \\
\hline
\end{tabular}

Proximal breadth

\begin{tabular}{|l|l|l|}
\hline \multirow{2}{*}{ Authors } & \multicolumn{2}{|l|}{ Proximal breadth } \\
\cline { 2 - 3 } & Male & Female \\
\hline Rashmi srivastava et.al ${ }^{2}, 2011$ & $85.72 \mathrm{~mm}$ & $75.29 \mathrm{~mm}$ \\
\hline Hema Nidugala et.al ${ }^{28} 2013$ & $76.74 \mathrm{~mm}$ & $79.78 \mathrm{~mm}$ \\
\hline Present study & $82.13 \mathrm{~mm}$ & $74.27 \mathrm{~mm}$ \\
\hline
\end{tabular}

Distal Breadth

\begin{tabular}{|l|l|l|}
\hline \multirow{2}{*}{ Authors } & \multicolumn{2}{|l|}{ Distal breadth } \\
\cline { 2 - 3 } & Male & Female \\
\hline Parson $^{16}, 1914$ & $\begin{array}{l}\text { More than } \\
75 \mathrm{~mm}\end{array}$ & Lesser than 70mm \\
\hline Pearson k,Bell J ${ }^{22}, 1917$ & More than & Lesser than72mm \\
\hline
\end{tabular}




\begin{tabular}{|c|c|c|}
\hline & $78 \mathrm{~mm}$ & \\
\hline $\begin{array}{l}\text { King C.A,iscan M.Y and Loth } \\
\text { S.R }^{19}, 1998\end{array}$ & $79.7 \mathrm{~mm}$ & $70 \mathrm{~mm}$ \\
\hline Mall G.Graw M,et.al $^{21}, 2000$ & $84 \mathrm{~mm}$ & $77 \mathrm{~mm}$ \\
\hline Purkait R. and Chandra $\mathrm{H}^{14}, 2002$ & $78.04 \mathrm{~mm}$ & $67.13 \mathrm{~mm}$ \\
\hline K.S. Narayana Reedy ${ }^{24}, 2008$ & 74 to $89 \mathrm{~mm}$ & 67 to $76 \mathrm{~mm}$ \\
\hline Apurba nandy ${ }^{25}, 2010$ & $75 \mathrm{~mm}$ & $70 \mathrm{~mm}$ \\
\hline Gargisoni et.al $^{15}, 2010$ & $76.27 \mathrm{~mm}$ & $69.26 \mathrm{~mm}$ \\
\hline Rashmi Srivastava e.tal $^{2}, 2011$ & $76.83 \mathrm{~mm}$ & $68.28 \mathrm{~mm}$. \\
\hline Umapathy Sembain et.al $^{12} 2012$ & $\begin{array}{l}\text { Rt.side } \\
73.6 \mathrm{~mm} \\
\text { Lt side } \\
75.0 \mathrm{~mm}\end{array}$ & $\begin{array}{l}\text { Rt side } 68.3 \mathrm{~mm} \\
\text { Lt side } 68.4 \mathrm{~mm}\end{array}$ \\
\hline Hema Nidugala et.al ${ }^{28} 2013$ & $70.19 \mathrm{~mm}$ & $73.87 \mathrm{~mm}$ \\
\hline Rajeswari.S. et.al ${ }^{29} 2013$ & $\begin{array}{l}\text { Rt side } \\
73.6 \mathrm{~mm} \\
\text { Lt side } \\
75.0 \mathrm{~mm}\end{array}$ & $\begin{array}{l}\text { Rt side } 68.3 \mathrm{~mm} \\
\text { Lt side } 68.4 \mathrm{~mm}\end{array}$ \\
\hline Mohammed Laeeque et.al $^{30} 2014$ & $76 \mathrm{~mm}$ & $65 \mathrm{~mm}$ \\
\hline Kalpana.R. et.al $^{20} 2014$ & $76.17 \mathrm{~mm}$ & $69.83 \mathrm{~mm}$ \\
\hline Pavel Timonov et.al ${ }^{18} 2014$ & $84.92 \mathrm{~mm}$ & 74.62 \\
\hline Present study & $74.79 \mathrm{~mm}$ & $69.38 \mathrm{~mm}$ \\
\hline
\end{tabular}

8. Van Gerven DP. The contribution of size and shape variation to patterns of sexual dimorphism of the human femur. Am J Phys Anthropol1972; 37: 49-60.

9. Singh,S.P and Singh,S (1972 A). The sexing of adult femora: Demark $\neg$ ing points for

10. Varanasi zone, Journal of the Indian Academy of Foren $\neg$ sic Sciences, 11:1-6.

11. Singh S. P. and Singh S., The sexing of adult femora:Demarking points for Varanasi zone, Journal of the Indian Academy of Forensic Sciences 1972 B; 11:1- 6.

12. Enock Prabhakar P (1988). In: Practical Mdico Legal Manual, a publi-cation of Indian Academy of Forensic Medicine.

13. Umapathy Sembian, Muhil. M, Srimathi.T, Muthukumar.T, Nalina Kumari.S.D-A Study of Sexual Dimorphism in Femora of Rural Population of South Tamilnadu, India,Journal of Clinical and Diagnostic Research. 2012 April, Vol-6(2): 163-165.

14. King CA, Iscan MY, Loth SR. Metric and comparative analysis of sexual dimorphism in the Thai Femur. J of Forensic Sci 1998;43(5):954-958.

15. Purkait R, Chandra H. Sexual Dimorphism in Femora: An Indian Study. Forensic Science Communications 2002; 4(3): 1-6.

16. Gargi S, Usha D, Sudha C. Determination of sex from femur: Discriminant analysis. J. Anat.Soc. India 2010; 59(2)216-221.

17. Parsons ,F.G. the character of English thigh bone:the difficulty of sexing.J.Anat 1914;49:335-361.

\section{Conclusion}

Asala SA,. Mbajiorgu FE, Papandro B.A. ${ }^{[23]}$ opined that the determination of the sex of an individual basing on a single factor is a more difficult task. Therefore, this study was conducted by taking a wider spectrum of the parameters (variable factors), ie, five factors, into consideration. The accuracy of the sex determination of the individual increases greatly due to this. Thus, the present study on the determination of sex of femora will be more reliable basis for the sex determination because it shows the values in this geographical region. This is believed to be more useful in the investigative procedures in the Forensic Medicine and also in the field of orthopaedics.

\section{Acknowledgement:}

Work attributed to Guntur medical college \& katuri medical college Guntur, Andhra Pradesh.

\section{References}

1. Krogman, W. M. and Iscan, M. Y. Human Skeleton in Forensic Medicine. 2nd Edition, Charles C. Thomas, Springfield, 1986.

2. Rashmi Srivastava, ph.D; Vineeta Saini, Ph.D; Rajesh K. Rai, M.D;Shashikant pandey, M.D; and Sunil K.Tripathi,M.D-A Study of sexual dimorphism in the Femur Among North Indians,2011 American Academy of Forensic Sciences .

3. Pandya A M, Singel TC,Akbari V J,Dangar K P,Tank K C,Patel M P-Vol 1 issue2 oct-Dec 2011-Sexual Dimorphism of Maximum Femoral length.

4. Cartmill M, Smith FH. The Human Lineage. Hoboken: John Wiley \& Sons, Inc, 2009.

5. Gruss LT. Limb length and locomotor biomechanics in the genus Homo: An experimental study. Am J Phys Anthropol2007;134:106-116.

6. Stanford C, Allen JS, Anton SC. Biological Anthropology. Upper Saddle River: Pearson Prentice Hall, 3rd edition, 2006.

7. Ward CV. Neuromusculo skeletal computer modeling and simulation of upright, straight legged, bipedal locomotion of Australopithecusafarensis (A.L.288-1). Am J Phys Anthropol 2002; 119 (35):185-215.

18. Rajeev vijay joshi1, Dr.Shema K Nair, Naresh thaduri, S.D.Gupta Morphometric Study of Proximal End of Femur in Central Indian Population 2017.

19. pavel timonov,Antoaneta fasova etal-astudy of sexual dimorphism in the femur among contemporary Bulgarain population 2014.

20. King CA, Iscan MY, Loth SR. Metric and comparative analysis of sexual dimorphism in the Thai Femur. J of Forensic Sci 1998;43(5):954-958.

21. kalpana R..Gaikwad,Dr. V.R.Nikam-sexual dimorphism in femur 2014 vol13.

22. Mall G,Graw M,Gehring KD,Hubing M. Determination of sex from femora.Forensic sci Int 2000;113-315-

23. Pearson K,Bell J.A Study of the long bones of the English skeleton.I.The femur .Biometry 1917/19:10-28.

24. S.A.Asala,Mbajiorgu,F.E. and papandro, B.A. A comparative study of femoral head diameter and sex determination in Nigerians.Acta Anatomica.1998; 162:232-237.

25. K.S.Narayana Reddy-Text book of the essentials of forensic medicine and Toxicology-27th edition, in 2008.

26. Apurba Nandy-text book of principles of Forensic Medicine-3rd edition, in 2010.

27. Dwight,T.The size of the articular surfaces of the long bones as characteristics of sex.An anthropological study.Amer.j.Anat.1905;4:19-32.

28. Stewart.TD.Essentials of Forensic anthropology:especially as developed in the united states.springfield.IL:Charles C Thomas, 1979.

29. Hema Nidugala,Bhagya bhaskar etal.-Metric Assessment of femur using Discriminant function analysis in south Indian population Int J Anat Res 2013, Vol 1(2):29-32.

30. Rajeshwari S. Bhosale,Dr. B.R. Zambare-sexual dimorphism of femur in Maharashtraian population. Vol 6,May-June 2013

31. Mohammed Laeeque vivek Nirmalae Chaya-Determination of sex of femur by combination of parameters 2011.

32. Susan standing etal-Text of Gray's Anatomy-40th edition-Gross Anatomy-Elsevier,Churchill.Living stone-2008.

33. Krishan Vij,MD,LLB Forensic Medicine and Toxicology, 5th edition 2011. 


\section{Kumari; Sexual Dimarphism of Femur and its Clinical Significance}

Copyright: (C) the author(s), publisher. Academia Anatomica International is an Official Publication of "Society for Health Care \& Research Development". It is an open-access article distributed under the terms of the Creative Commons Attribution Non-Commercial License, which permits unrestricted non-commercial use, distribution, and reproduction in any medium, provided the original work is properly cited.

How to cite this article: Kumari RDKVP. Sexual Dimorphism of Femur and its Clinical Significance. Acad. Anat. Int. 2019;5(1):116-121. DOI: dx.doi.org/10.21276/aanat.2019.5.1.28

Source of Support: Nil, Conflict of Interest: None declared. 